\title{
A REVIEW ON MARINE ALGAE AND ITS APPLICATIONS
}

\author{
CHANDRA VELUCHAMY ${ }^{1}$, RADHA PALANISWAMY2*
}

${ }^{1}$ Department of Biotechnology, , School of Bio Sciences and Technology, Vellore Institute of Technology, Vellore, Tamil Nadu, India. ${ }^{2}$ Department of Biotechnology, Dr. NGP Arts and Science College, Coimbatore, Tamil Nadu, India. Email: palaniswamyradha@gmail.com

Received: 25 October 2019, Revised and Accepted: 14 January 2020

ABSTRACT

The ocean is the major essential source of structurally unique natural products that are mainly present in living organisms. The essential products extracted from marine microbes and marine algae are highly analyzed areas in instinctive product research. Marine algae are the novel food with potential nutritional values used for multiple purposes in industry and medicine. They show pharmacological activities which are helpful for the invention of bioactive compounds. Furthermore, marine algae have shown to provide an abundant source of natural bioactive compounds with antidiabetic, anti-inflammatory, antiviral, antifungal, hypolipidemic, antioxidant, anti-hypercholesterolemia, antibacterial, and antineoplastic properties. They produce new secondary metabolites that possess biological activities and have the potential to be developed as therapeutic agents. Macroalgal lectins, fucoidans, kainoids, and other substances have been routinely used in the research of biomedical and also have biological activities. The potential pharmaceutical, medicinal, and research applications of these compounds are discussed.

Keywords: Algae, Marine organisms, Bioactive compounds, Nutraceutical.

(C) 2020 The Authors. Published by Innovare Academic Sciences Pvt Ltd. This is an open access article under the CC BY license (http://creativecommons. org/licenses/by/4. 0/) DOI: http://dx.doi.org/10.22159/ajpcr.2020.v13i3.36130

\section{INTRODUCTION}

Marine algae are plant-like organisms that are typically found fixed on rock or other hard bases in coastal areas. Red and brown algae are found in marine, while green algae are also found in freshwater (rivers and lakes) and even in rocks, walls, and tree bark in damp places [1]. The orderly systematic study of algae is called phycology. They have multiple kinds of life cycles and size from microscopic Micromonas species to giant kelps that extend about $60 \mathrm{~m}$ in length. Due to abundant availability in the marine ecosystem, marine algae become very good sources of bioactive compounds such as dietary fiber, omega-3 fatty acids, carotenoids, vitamins, and minerals [2]. Their cells have unique features that have not found among plants and animals. Photosynthetic pigments are also different than plant. Algae provide a broad range of therapeutic beneficial both internally and externally. They are oxygen producers and also the food base for all aquatic life almost and economically main as a source of crude oil, food, and many pharmaceutical and industrial products for humans. The bioactive potential of different marine algae has been reviewed in the literature [3-6].

\section{ALGAL CLASSIFICATION}

There are three main classifications of algae - Chlorophyceae are green algae that contain the pigments chlorophyll $a$ and $b$. (i.e., Chlamydomonas, Spirogyra, and Chara). Phaeophyceae are brown algae, they are mainly present in marine. They contain pigments such as chlorophyll A, C, carotenoids, and xanthophyll (i.e. Dictyota, Laminaria, and Sargassum). Rhodophyceae are red algae that contain the red pigment, r-phycoerythrin (i.e., Porphyra, Gracilaria, and Gelidium). The fourth type of algae is blue-green algae (BGA) (Cyanobacteria) that are occasionally treated to be seaweed. This type of algae is often found in home aquariums where it will cover all surfaces in a short time and called as slime algae or smear algae [7].

\section{ALGAL ULTRASTRUCTURE}

The term algae (Latin - seaweeds) were first introduced by Linnaeus in 1753, meaning the Hepaticae. They can be single celled or multicellular. Living thing types of protoctist also are known as cell-free protoctist as they operate as total living organisms. They are common in all types of algae except Charophyceae, Phaeophyceae, and Rhodophyceae. The unicells may be motile or non-motile. The larger, multicellular algae have relatively complex tissues, which can be organized into organ-like structures that help certain functions [8]

Algae have chloroplasts for the process of photosynthesis and the algal cell wall is mostly cellulosic. It also contains hemi-cellulose, mucilage, pectin, and other substances such as alginic acid, fucoidan, fucin, calcium carbonate, and silica. Chloroplasts are the most renowned feature of algal cells and they carry the photosynthetic pigments which are double membrane structures. Beating action of small filiform or thread-like protoplasmic appendages which is called as flagella helps for the movement [9].

\section{ALGAL BIODIVERSITY}

Indian coastline is longer about $5700 \mathrm{~km}$ including nine states on the mainland and about $7500 \mathrm{~km}$ including islands and union territories. Coasts with the broadest diversity of algae present in both temperate and tropical seas [10]. Algae are ubiquitous in marine, freshwater, and terrestrial habitats. The phylogenetic diversity of the algae is very broad and is reflected in an equally wide range of metabolisms and biochemical properties. A kind of brown algae develops the giant kelp forests near the California coast, while the other develops the floating kelp beds in the Sargasso Sea, a region of the North Atlantic Ocean. The golden brown algae (chrysophytes) are common microscopic organisms that provide food for zooplankton in freshwater. In general, it is found to be more than 6000 species of red algae. The typical red algae (Rhodophyta), a rose-colored multicellular organism is found globally. This alga can be found and live in deeper depth than brown and green algae because it takes in blue light. Another class of algae is Xanthophyta which are yellow-green algae that live in freshwater. Nearly 7000 species of green are spotted, according to the UC Museum of Paleontology. Freshwater green algae like Spirogyra in Charophyta phylum are highly related to plants. Green algae may present in marine or freshwater habitats, and some even grow in slightly wet soils. For example, sea lettuce (Ulva sp.) generally found in tidal pools and Codium sp., one species of which is commonly called "dead man's fingers" [7].

\section{EDIBLE AND POISONOUS ALGAE}

Edible seaweed which comes under the type of brown algae is a vegetable of the sea, a food source for ocean life and humans who 
consume it in its many forms. Low-calorie and nutrient-dense, edible seaweed has long been harvested and consumed in Asian cuisines, particularly those of Japan and Korea. Six common types of seaweed are in the list of Japanese human diet and they are commonly called Nori, Kombu, Wakame, Ogonori, Umibudo, and Hijiki [11]. One of the edible green seaweed called sea lettuce grows in the coastlines of the world's oceans. It is one of the important food for sea animals such as sea slugs and manatees and humans also eaten it for centuries. Marine algae Spirulina have an exceptionally high protein content of which $90 \%$ is digestible. Spirulina is a microalga which might be a promising source of protein for human nutrition in protein deficiency or malnutrition [12]. On the other hand, some algae can be harmful to humans. For example, a disease of the humans called ciguatera caused by the consumption of tropical fish which fed on the alga such as Gambierdiscus or Ostreopsis can be disastrous. Other algae called Heterosigma (class Raphidophyceae) and Dictyocha (class Dictyochophyceae) are suspected fish killers. Some seaweeds have high concentrations of arsenic when eaten and may cause arsenic poisoning. Hizikia is brown algae that contain adequate amount of arsenic to be used as a rat poison [13]

\section{ANTIOXIDANT ACTIVITIES}

Antioxidant activities were identified in different types of marine algae such as red, green, and brown algae species [14]. Out of the total 5000 fresh water habitat reported, approximately $3 \%$ is Rhodophyta, the red algae [15]. Ethanol extracts of the Callophyllis japonica [16] and Gracilaria tenuistipitata [17] species of red algae have antioxidant effects. Ethanol extracts of $C$. japonica suppressed cellular apoptosis and active antioxidant enzymes [16]. Studies were examined with the H1299 cell line which showed that treatment with an aqueous extract of $G$. tenuistipitata enhanced the recovery of these cells from $\mathrm{H}_{2} \mathrm{O}_{2}$ induced DNA damage, counteracts cellular proliferation, and induced G2/M arrest [17]. Green algae - these algae are found in lakes, oceans, and fresh water bodies. Some even grow in soils and live in tree trunks. The overall population of green algae is estimated to be more than 500 genera and 8500 species [18]. Free radical scavenging tests revealed the antioxidant activity of Ulva fasciata Delile due to the presence of sesquiterpenoids [19]. Flavonoids are rich in Ulva lactuca and having great antioxidant properties [20]. Extraction of Ulva reticulata using hot water reduced hepatic oxidative stress [21]. Seaweed U. reticulata occurs on the Kanyakumari coast of India. BGA or Cyanobacteria belong to the photosynthetic prokaryotes existing in the aquatic ecosystems. Few BGA species such as Aphanizomenon flos-aquae, Spirulina platensis, Spirulina maxima, Spirulina fusiformis, and Nostoc commune var. sphaeroids Kutzing (NO) are consumed by major population of humans for centuries [22-26]. They are generally prevalent in tidal pools. The antioxidant effects of Anabaena species methanol extract were revealed by DPPH radical scavenging activity [27]. The antioxidant effect of phycobiliprotein phycocyanin in S. platensis was analyzed by ascorbate/ iron $/ \mathrm{H}_{2} \mathrm{O}_{2}$ assays [28].

\section{ANTICANCER EFFECTS OF MARINE ALGAE}

Cell proliferation of human leukemic cell lines was inhibited using the aqueous extracts of Gracilaria corticata [29] and Sargassum oligocystum [30]. Similarly, ethanol [31] and methanol [32] extracts of $G$. tenuistipitata were reported to have antiproliferative activity on Ca9-22 oral cancer cells and also responsible for cellular apoptosis, oxidative stress, and DNA damage. Methanolic extract of Plocamium telfairiae-induced caspase-dependent apoptosis in HT-29 colon cancer cells [33]. Glycoproteins from Laminaria japonica [34] and fucoidans from Sargassum hornery, Ecklonia cava, and Costaria costata [35] exhibited anticancer effects on human colon cancer cells. Hetero fucans extracted from Sargassum filipendula showed antiproliferative property on cervical, prostate, and liver cancer cells [36]. BGA also confirmed the anticancer effects of Spirulina extracted [37] recombinant glycoproteins, in specific Microcystis viridis lectin [38], and cryptophycin [39,40]. The red algae Laurencia viridis are an essential source of squalenederived secondary metabolites. Three squalene-derived brominated triterpenes dehydrothyrsiferol [41], isodehydrothyrsiferol [42], and 10-epidehydrothyrisiferol [43] were isolated from L. viridis, exhibited potent cytotoxic activity besides a number of cancer cell lines.

\section{AGRICULTURAL PRODUCTS FROM ALGAE}

Algal extracts have several applications in the field of agriculture such as fertilizers, plant biostimulants, or bioregulators of plant growth. Plant growth regulators are different from fertilizers because they alter cell division, root and shoot elongation, flowering, and other metabolic functions, whereas fertilizers only provide nutrients essential for the growth of plants [44]. Cytokinin is the most important plant growth regulator in seaweed. However, trace minerals extracted from seaweed play a major role in nutrition and physiology, acting as enzyme activators [45].

\section{ANIMAL PRODUCTS FROM ALGAE}

Seaweed extracts can be potentially exploited as feed additives [46] due to their performance in growth and reduction of pathogenic bacteria [47]. Algae and their extracts have many beneficial effects as food additives. Humans lag behind in algal diets and are currently formulated as commercially potent species in aquaculture and agriculture. Many algal species exhibit beneficial effects in poultry, mammals (nematodes, shrimp, and abalone), finfish (sea bream to salmon), and sheep (both ruminants and monogastric species) [48]. The antioxidant properties of astaxanthin (red-colored carotenoid) are extracted from green alga Haematococcus pluvialis. It was shown that the supplementation of astaxanthin-rich extract to the diet of mice improved cholesterol and lipid metabolism as well as antioxidant defense mechanisms [49]. This action was helpful in mitigating the progression of atherosclerosis [50].

\section{COSMETIC PRODUCTS FROM ALGAE}

Algae are the potential organisms playing a key role in the current research and development, producing new biochemically active compounds [51]. Algal extracts are used mostly in the face and skin care products, anti-aging cream, regenerating skin cream, emollient products, anti-irritant products, sun protection cream, and hair care products [52]. Algal extracts have been already used as sources of cosmeceuticals. Extractions of carotenoids and astaxanthin from marine algal species have received more attention for cosmeceutical purposes. Carotenoids and astaxanthin extracted from marine algae were explored for cosmeceutical purposes [53]. Extract of brown seaweeds (containing fucoidan fractions) are applicable in cosmetology as fibroblast proliferation activators in treatments aimed at aesthetics, for example, in anti-wrinkle treatments or in the prevention of skin aging without patent infringement [54]. The methanolic extract of Corallina pilulifera exhibited strong antioxidant activity and displayed a protective effect on ultraviolet A-induced oxidative stress of the human dermal fibroblast cell. The obtained results suggested that macroalgal extract may be a potential source of natural anti-photoaging compounds [55].

\section{BACTERICIDAL ACTIVITY}

The phlorotannins present in brown algae are effective against certain pathogenic foodborne bacteria. The growth of Campylobacter jejuni and Vibrio parahaemolyticus has been suppressed by dieckol and 8,8-bieckol, phlorotannins isolated from Ecklonia kurome [56]. Campylobacter spp. was reported to be most susceptible to phlorotannins and the growth of Staphylococcus aureus was effectively reduced by phlorotannins present in the hexane fraction of Ecklonia stolonifera [57]. Their antibacterial activity is based on their molecular weight. Another compound, phlorotannin containing extract of brown seaweed Ascophyllum nodosum has been shown to reduce the prevalence of Escherichia coli 0157:H7 in bovine feces [58].

\section{PHARMACEUTICAL INDUSTRY}

Marine algae, an important source of bioactive metabolites has a key role in drug development area inside pharmaceutical industry. Vast studies have been conducted on algae-based bioactive compounds from Arthrospira (Spirulina), Dunaliella salina, Botryococcus braunii, 
Chlorella vulgaris, Nostoc, and H. pluvialis and with high antimicrobial, anticoagulant, antiviral, antifungal, antienzymatic, anti-inflammatory, antioxidant, and antitumor activity [59-63]. Protoctists have a good ability to fold proteins into advanced three-dimensional structures. In San Diego, algae produced human antibodies and human therapeutic drugs such as human vascular endothelial growth factors for treating patients affected by pulmonary emphysema [64]. Chlamydomonas reinhardtii, the green algae model produces many therapeutic proteins for human and animals including full-length human antibodies [65]. Production of bioactive compounds by green algae is a fortunate thing to pharmaceutical research [66-70]. The biomass of Nostoc is being used as a dietary supplement composing rich protein, lipids, and fatty acid content. The clinical value has been established for these microalgae due to its application in curing fistula and also certain type of cancer [71].

\section{PAINT, PRINTING, AND DYING INDUSTRY}

Green algae are applied as natural anti-fouling agent in the recently developed paints. Macroalgae produce an array of natural compounds to protect itself from natural enemies [72]. Asparagopsis, Laurencia (red algae), and Sargassum (brown algae) act as an important source of antifouling compounds. At present, one omaezallene and four polyether triterpenoids are reported with anti-macrofouling activity from Laurencia sp. and L. viridis, respectively [73]. Dai Nippon Ink and Chemical Company from Japan extracted a blue phycocyanin from S. platensis and sold to the market as a natural blue pigment called "lina blue" which is commercially used in food preparation and cosmetic products. Other applications are confectionaries, candied ices, and sherbets [74].

\section{ANTI-INFLAMMATORY SUBSTANCES}

Microalgal biomass is capable to produce several anti-inflammatory compounds. Due to their anti-inflammatory properties, they are considered for applications in tissue engineering for the development of scaffolds and also for reconstitution of organs and tissues $[75,76]$. $\beta$-1,3-glucan, an important bioactive compound extracted from Chlorella acts as an active immune stimulator for free radical and blood cholesterol reduction. The effect of this compound in curing gastric ulcers, sores, and constipation has been studied. It is also demonstrated to prevent the occurrence of diseases such as atherosclerosis and hypercholesterolemia and proved to have some antitumor activity [52]. Sulfated polysaccharides (SPs) having anti-inflammatory activity are used for skin treatments by inhibiting the mobility and adhesion of polymorphonuclear leukocytes [77].

\section{ANTIMICROBIAL ACTIVITY}

Another study conducted by $M$. Kuniyoshi proved that the algae Cladophora have antimicrobial activity against certain microorganisms. The green algal extract of Cladophora fascicularis was separated using different chromatographic techniques to collect 2-(20,40-dibromophenoxy)-4,6-dibromoanisol [78]. It also actively inhibited the growth of E. coli, Bacillus subtilis, and S. aureus [78].

\section{ANTIFUNGAL ACTIVITY}

Capisterones, a triterpene sulfate esters present in green algae Penicillus capitatus have high antifungal property against algal pathogen Lindra thallasiae [79]. Crude extracts from certain red algal species were examined for the presence of antibiotic activity against few pathogenic fungi [80]. The eminent fungicidal activity was found in marine macroalgae to recover patients from chronic asthmatic states. In particular, L. paniculata was studied to have excellent antifungal activity and so it is recommended as a promising candidate to attain a novel antifungal agent [81].

\section{ANTICOAGULANT ACTIVITY}

More than 50 years, heparin is widely used commercially for the prevention of venous thromboembolic disorders. However, heparin is reported to have many side effects such as development of thrombocytopenia, acquired antithrombin deficiencies, and congenital ineffectiveness in inhibiting thrombin bound to fibrin [82].
Investigations on blood anticoagulant properties from marine brown algae [83] report that SPs act as an alternative source for novel anticoagulant drugs [84-86]. Anticoagulant activity is one of the most widely considered properties of SPs $[87,88]$. Many other anticoagulants with SPs are isolated and characterized. Sulfated galactans (carrageenan) and sulfated fucoidans from marine red algae [89-91] and brown algae, respectively, are the two types of SPs identified with significant level of anticoagulant activity [92-94].

\section{ANTIVIRAL ACTIVITY}

The antiviral efficacy of marine algal polysaccharides was first revealed by Gerber et al. [95] who studied the effect of polysaccharides extracted from Gelidium cartilagineum (Rhodophyceae) in protecting the embryonic eggs from influenza B or mump virus. These polysaccharides that are possessing antiviral activity are found to be highly sulfated [96]. The replication of enveloped viruses such as Orthopoxvirus, flavivirus, herpesvirus, togavirus, rhabdovirus, and Arenavirus families is inhibited by many species of marine algae having significant complex structural SPs [97]. Polysaccharides have engrossed much consideration as antiviral compounds due to their inhibition of algal polysaccharides against mumps and influenza virus [98]. Several fucans from the seaweed species Dictyota mertensii, Lobophora variegata, Spatoglossum schroederi, and Fucus vesiculosus were reported to successfully inhibit the activity of HIV reverse transcriptase [99]. Griffithsia sp. (red algae) are the source for a novel lectin, identified as Griffiths in having molecular weight of $12.7 \mathrm{kDa}$. This protein made of 121 amino acids is reported to demonstrate promising anti-HIV activity [100].

\section{HYPOGLYCEMIC EFFECT}

Diabetes mellitus belongs to the group of diseases that occur due to excess sugar in the blood (high blood glucose). It happens to be the most important metabolic disease with fast increasing prevalence, which is a major public health concern worldwide. The brown macroalgae, $S$. oligocystum, improve the diabetic by reducing insulin resistance, decreasing glucose concentration and regeneration of pancreatic damaged $\beta$-cell [101]. Fucosterol, isolated from Pelvetia siliquosa, was shown to decrease serum glucose levels and to inhibit glycogen degradation in streptozotocin-induced diabetic rats [102]. High $\alpha$-glucosidase inhibitory activity is found in Pelvetia babingtonii (Harvey) De Toni (Fucaceae) extract which also suppress postprandial hyperglycemia [103] . A. nodosum (L.) Le Jolis, a brown algae predominant in dominant rocky intertidal grow profusely on the northeastern coast of North America and the northwestern coast of Europe [104]. Water extracts of the algae have strong inhibition for $\alpha$-glucosidase and its phenolic compounds which indirectly lower the blood glucose levels [105]. Eisenia bicyclis (Kjellman) Setchell (Lessoniaceae), an enduring and day-to-day consumed edible brown alga lives in the middle of Pacific seashores of Korea and Japan. Derivative of phloroglucinol, isolated from E. bicyclis, shows high potential for the elective therapy for diabetic complicated patients by inhibition of advanced glycation end products formation and $\alpha$-amylase activity [106]. Fucoxanthin is a marine carotenoid extracted from edible brown macroalgae, namely, E. bicyclis (Arame) and Undaria pinnatifida (Wakame), is found to cure insulin resistance and also to ameliorate blood glucose levels [107]. Polysaccharides isolated from U. lactuca could significantly decrease the blood glucose by their potential inhibitory effect on key enzymes closely related to starch digestion and absorption in both plasma and small intestine [108]. In another study, the ethanolic extract of Ulva rigida was reported to decrease the blood glucose concentrations and occurrence of micronuclei in diabetic rats $[109,110]$.

\section{NUTRITIONAL APPLICATIONS}

Global demand for nutritional food apart from traditional and nutritional values is to use the food for functional values too. Seaweeds contribute as a balanced diet, on providing fiber, protein, minerals, vitamins, and low-fat carbohydrate content [111]. The prominent trait of Chlorella is the presence of rich protein and vitamin (singlecell protein). It contains Vitamins $\mathrm{C}$, pro-Vitamin $\mathrm{A}$, thiamine, 


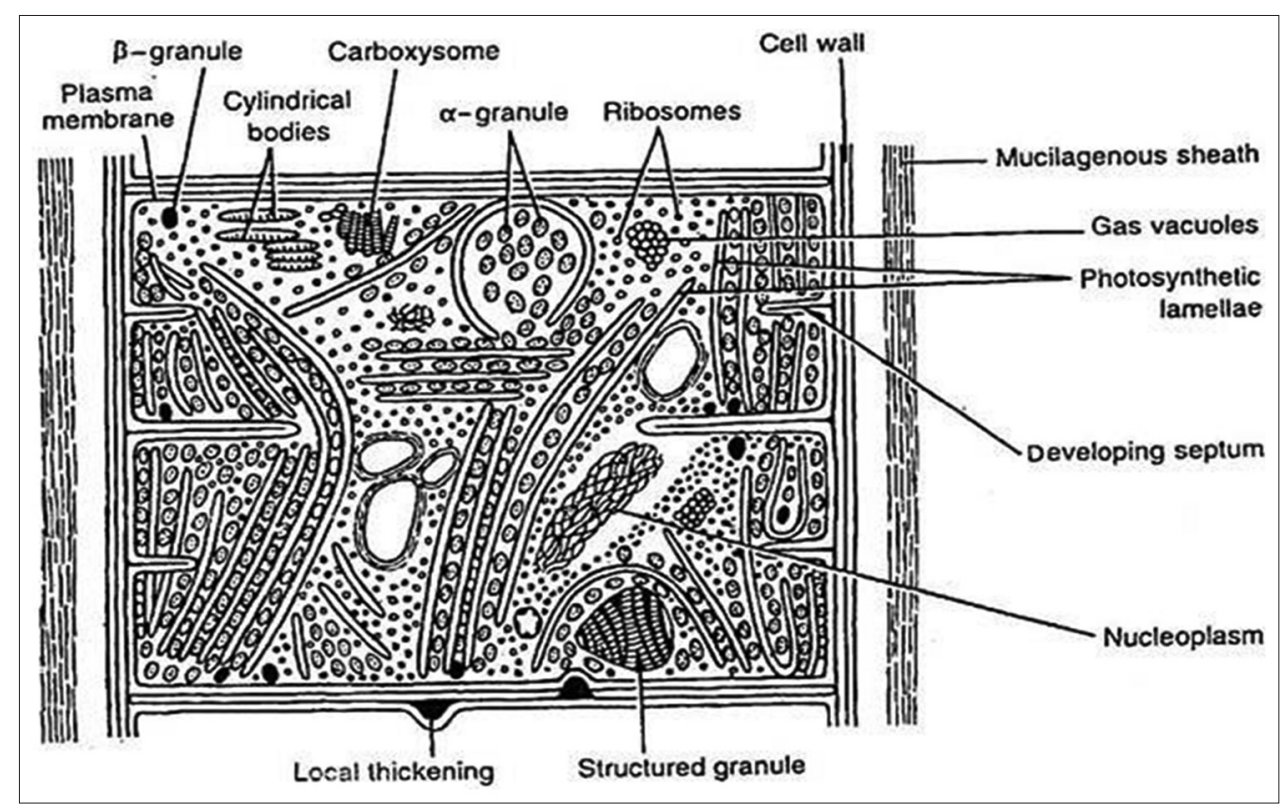

Fig. 1: - Structure of a prokaryotic cell (blue green algae) under electron microscope [9]

riboflavin, pyridoxine, niacin, pantothenic acid, folic acid, inositolm and p-aminobenzoic acid. It possesses all the essential amino acids well suited for both human beings and animals [112]. One such food is BGA, Spirulina, which has been a part of the human diet for thousands of years as per archeological evidence. The potential health benefits of Spirulina must be adequately recognized and implemented thus making full use of this nature's gift. The global availability across all the regions of the world makes algae easily offered at economical prices for access to all classes of the population [113]. Seaweeds are eaten as whole foods by a relatively small percentage of the world population, in a relatively limited geography. Scientists in the Asian countries have reported that the Japanese are the largest consumers of marine algae reporting an annual consumption per individual as $1.6 \mathrm{~kg}$ dry weight, which contributes immense health benefits $[114,115]$.

\section{ECONOMICAL IMPORTANCE OF ALGAE}

Algae are cost effectively vital due to its broad spectra of applications as food, fodder, pisciculture, fertilizer, etc. They are a healthy source of carbohydrates, fats, proteins, and Vitamins A, B, C, and E as well as minerals such as iron, potassium, magnesium, calcium, manganese, and zinc. People of countries such as Ireland, Scotland, Sweden, Norway, North and South America, France, Germany, Japan, and China use it as food ingredients for centuries. Protoctist is used because the fodder to feed placental mammallike bovine and chickens. In aquaculture, algae are predominant in the production practice. Plankton and zooplankton are the food consumed by fishes. It helps to balance a healthy marine ecosystem, as algae act as natural $\mathrm{CO}_{2}$ sequester and $\mathrm{O}_{2}$ provider [116]. Heavy metal pollution from various industries and other domestic sources is a serious threat to the aquatic ecosystem, ultimately leading to loss of biological diversity and biomagnifications of toxic metals into the food chain. Algae are the major organisms that absorb and store heavy metals. Since algae are present at the base of the aquatic food chain, they are a very important vector for bringing up pollution to the top levels of the tropical food chain in aquatic environments [117]. Some common forms of Cyanophyceae help in fixing atmospheric nitrogen and also to enrich the soil [118].

\section{ALGAE PRODUCTION IN GLOBAL MARKET}

The global algae production is segregated on the basis of type, source, form, application, and region. Based on the type, the algal market is labeled as Spirulina, Chlorella, Astaxanthin, beta-carotene, and hydrocolloids. Based on source, the global algal produce is categorized into brown algae, BGA, red algae, and green algae. Based on region, it is classified across the globe in North America, Europe, Asia-Pacific, and LAMEA [119]. The overall space used for the cultivation of Porphyra throughout Japan is estimated around 155 acres. Approximately every year 4000-5000 metric tons of algae (dry weight) are being produced and it creates a hike in revenue compared to other marine products including fish and whales. Laminaria cultivated excessively in Japan and China. The cultivation of algae resembles more of a crop plant, resulting in the evolution of a strong economic crop. In many countries, factories are established for processing of seaweed into appropriate cattle feed [112]. Consumption of healthy edible produce and dietary supplements, due to changes in the lifestyle of the people, has changed the perspective of this market. Fig. 1 shows the ultrastructure of the algae. The annual growth rate of algal product market is estimated to increase by $4.2 \%$ between 2018 and 2025 due to the high demand for natural products. The market players put forward proactive efforts to formulate algae-based edible products to meet the required quality, texture, and nutritional demand of consumers [119].

\section{INDIAN SCENARIO OF ALGAL MARKET}

A new series of drug and nutrition-based products are recently being developed from algae. Spirulina, one of the important pharmaceutical products is having high market demand in India [120]. Over the past 15 years, India stands as one of the major producers of algal biomass [121]. Herbal hills: Herbal hills cultivate manufactures and export various ayurvedic herbal products and various algae products as Spirulina tablets in India. In India, Shibin Chlorella is the foremost company in the commercial production as a nutritional supplement from July 2015. Parry Nutraceuticals: The corporate is one the simplest providing microalgal health supplements, with headquarters in city, and a division of E.I.D. Parry (I) Ltd. In India, algae company is the pioneer company focusing dutiful on algae as nutraceuticals. The main products of the company are Chlorella factor that provides a potential food candidate due to its high protein content and other nutrients, it contains up to $20 \%$ carbohydrate, $5 \%$ fiber, $10 \%$ minerals and vitamins, and up to $45 \%$ protein in its dry weight. Organic Spirulina contains up to $60 \%$ protein with over 100 times more protein content as found in fruits and nuts. Zenith nutrition: This company provides a broad range of products such as vitamins, probiotics, herbal formulations, and amino acids. This is a leading company involved in high-quality research for providing formulations to benefit health [122].

\section{AVAILABLE FORMS OF ALGAE}

Global demand is high for macroalgal and microalgal foods because algae have many functional benefits compared to traditional aspects 
of nutrition and health care [123]. For centuries, marine algae are predominant in the field of food and drugs. Algal species have the applications in food diary pharmaceuticals, industry, and cosmetics. Biodiesel, hydrogen gases, biobutanol, and bioethanol can be prepared by algae [124]. The available form of algae is oil, soft starch capsules, tablets, and powders. Algae can be consumed in the form of capsules, tablets, or powders. Since 2003, the oil that is rich in omega-3 fatty acids obtained from the microalgae Schizochytrium sp. and containing docosahexaenoic acid and some eicosapentaenoic acid has been approved in Europe as a novel food [125].

\section{AUTHORS' CONTRIBUTIONS}

Collection of data and written by Chandra Veluchamy and it was edited by Dr. Radha Palaniswamy.

\section{CONFLICTS OF INTEREST}

There are no conflicts of interest.

\section{AUTHORS' FUNDING}

It is not funded since it is not supported by any agency.

\section{REFERENCES}

1. Available from :https://www.leviathan-cycle.com/essays/ algarium veneticum/\#targettext $=$ marine $\% 20$ algae $\% 20$ are $\% 20$ plant $\% 2$ dlike,bark $\% 20$ in $\% 20$ damp $\% 20$ places) $\% 20$ situations.

2. Available from: https://www.britannica.com/science/ algae\#targetText $=$ Algae $\% 20$ have $\% 20$ many $\% 20$ types $\% 20$ of, $(200 \% 20$ feet) $\% 20 \mathrm{in} \% 20$ length.

3. Li YX, Wijesekara I, Li Y, Kim SK. Phlorotannins as bioactive agents from brown algae. Process Biochem 201146 2011;46:2219-24.

4. Lordan S, Ross RP, Stanton C. Marine bioactives as functional food ingredients: Potential to reduce the incidence of chronic diseases. Mar Drugs 2011;9:1056-100

5. Vo TS, Kim SK. Fucoidans as a natural bioactive ingredient for functional foods. J Funct Foods 2013;5:16-27.

6. Wijesinghe WA, Jeon YJ. Enzyme-assistant extraction(EAE) of bioactive components: A useful approach for recovery of industrially important metabolites from seaweeds: A review. Fitoterapia 2012;83:6-12.

7. Available from: https://www.thoughtco.com/types-of-marinealgae-2291975.

8. Available from: http://www.biologydiscussion.com/algae/algae-definitioncharacteristics-and-structure-with-diagram/46727

9. Available from: http://www.biologydiscussion.com/algae/cellstructures-in-algae-with-diagram/46759.

10. Available from: https://www.tandfonline.com/doi/abs/10.2216/i00318884-35-4-308.1.

11. Available from: https://www.guide.michelin.com/en/article/dining-in/6edible-delicious-varieties-of seaweed.

12. Tang G, Suter PM. Vitamin A nutrition and health values of algae: Spirulina, Chlorella and Dunaliella. J Pharm Nutr Sci 2011;2:111-8.

13. Available from: https://www.britannica.com/science/algae/toxicity.

14. Kelman D, Posner EK, McDermid KJ, Tabandera NK, Wright PR, Wright AD. Antioxidant activity of Hawaiian marine algae. Mar Drugs 2012;10:403-16.

15. Robert G. Sheath Office of Provost and Vice President for Academic Affairs. San Marcos, California: California State University; 2003.

16. Kang KA, Bu HD, Park DS, Go GM, Jee Y, Shin T, et al. Antioxidant activity of ethanol extract of Callophyllis japonica. Phytother Res 2005; 19:506-10.

17. Yang JI, Yeh CC, Lee JC, Yi SC, Huang HW, Tseng CN, et al. Aqueous extracts of the edible Gracilaria tenuistipitata are protective against $\mathrm{H}_{2} \mathrm{O}_{2}$-induced DNA damage growth inhibition and cell cycle arrest. Molecules 201217 2012;17:7241-54

18. Available from: http://www.differencebetween.net/science/biologyscience/difference-between-cyanobacteria-and-green-algae.

19. Chakraborty K, Paulraj R. Sesquiterpenoids with free-radicalscavenging properties from marine macroalga Ulva fasciata Delile. Food Chem 2010;122:31-41.

20. Meenakshi S, Gnanambigai DM, Mozhi ST, Arumugam M, Balasubramanian T. Total flavanoid and in vitro antioxidant activity of two seaweeds of Rameshwaram coast. Global J Pharmacol 2009;3:59-62.

21. Rao HB, Sathivel A, Devaki T. Antihepatotoxic nature of Ulva reticulata (Chlorophyceae) on acetaminophen-induced hepatoxicity in experimental rats. J Med Food 2004;7:495-7.

22. Madhyastha HK, Radha KS, Sugiki M, Omura S, Maruyama M. Purification of c-phycocyanin from Spirulina fusiformis and its effect on the induction of urokinase-type plasminogen activator from calf pulmonary endothelial cells. Phytomedicine 2006;13:564-9.

23. Parikh P, Mani U, Iyer U. Role of Spirulina in the control of glycemia and lipidemia in Type 2 diabetes mellitus. J Med Food 2001;4:193-9.

24. Torres-PV TT, Ferreira-A FF, Juarez-MA JJ. Antihyperlipemic and antihypertensive effects of Spirulina maxima in an open sample of Mexican population: A preliminary report. Lipids Health Dis 2007;6:-33.

25. Rasmussen HE, Blobaum KR, Jesch ED, Ku CS, Park YK, Lu F, et al. Hypocholesterolemic effect of Nostoc commune var. sphaeroides Kützing, an edible blue-green alga. Eur J Nutr 2009;48:387-94.

26. Hori K, Ishibashi G, Okita T. Hypocholesterolemic effect of blue-green alga, ishikurage (Nostoc commune) in rats fed atherogenic diet. Plant Foods Hum Nutr 1994;45:63-70.

27. Pant G, Kumar G, Karthik L, Prasuna RG, Rao KV. Antioxidant activity of methanolic extract of blue green algae Anabaena sp. Eur J Exp Bio 2011:1:156-62

28. Piñero Estrada JE, Bermejo Bescós P, Villar del Fresno AM. Antioxidant activity of different fractions of Spirulina platensis protean extract. Farmaco 2001;56:497-500.

29. Zandi K, Tajbakhsh S, Nabipour I, Rastian Z, Yousefi F, Sharafian S, et al. In vitro antitumor activity of Gracilaria corticata (a red alga) against Jurkat and molt-4 human cancer cell lines. Afr J Biotechnol 2010;9:6787-90.

30. Zandi K, Ahmadzadeh S, Tajbakhsh S, Rastian Z, Yousefi F, Farshadpour F, et al. Anticancer activity of Sargassum oligocystum water extract against human cancer cell lines. Eur Rev Med Pharmacol Sci 2010;14:669-73.

31. Yeh CC, Tseng CN, Yang JI, Huang HW, Fang Y, Tang JY, et al. Antiproliferation and induction of apoptosis in Ca9-22 oral cancer cells by ethanolic extract of Gracilaria tenuistipitata. Molecules 2012;17:10916-27

32. Yeh CC, Yang JI, Lee JC, Tseng CN, Chan YC, Hseu YC, et al. Antiproliferative effect of methanolic extract of Gracilaria tenuistipitata on oral cancer cells involves apoptosis, DNA damage, and oxidative stress. BMC Complement Altern Med 2012;12:142.

33. Kim JY, Yoon MY, Cha MR, Hwang JH, Park E, Choi SU, et al. Methanolic extracts of Plocamium telfairiae induce cytotoxicity and caspase-dependent apoptosis in HT-29 human colon carcinoma cells. J Med Food 2007;10:587-93.

34. Go H, Hwang HJ, Nam TJ. A glycoprotein from Laminaria japonica induces apoptosis in HT-29 colon cancer cells. Toxicol In Vitro 2010;24:1546-53.

35. Ermakova S, Sokolova R, Kim SM, Um BH, Isakov V, Zvyagintseva T. Fucoidans from brown seaweeds Sargassum hornery, Eclonia cava, Costaria costata: Structural characteristics and anticancer activity. Appl Biochem Biotechnol 2011;164:841-50.

36. Costa LS, Fidelis GP, Telles CB, Dantas-Santos N, Camara RB, Cordeiro SL, et al. Antioxidant and antiproliferative activities of heterofucans from the seaweed Sargassum filipendula. Mar Drugs 2011;9:952-66

37. Khan Z, Bhadouria P, Bisen PS. Nutritional and therapeutic potential of Spirulina. Curr Pharm Biotechnol 2005;6:373-9.

38. Li Y, Zhang X. Recombinant Microcystis viridis lectin as a potential anticancer agent. Pharmazie 2010;65:922-3

39. Shih C, Teicher BA. Cryptophycins: A novel class of potent antimitotic antitumor depsipeptides. Curr Pharm Des 2001;7:1259-76.

40. Corbett TH, Valeriote FA, Demchik L, Polin L, Panchapor C, Pugh S, et al. Preclinical anticancer activity of cryptophycin-8. J Exp Ther Oncol 1996;1:95-108.

41. Campo VL, Kawano DF, Silva DD, Carvalho I. Carrageenans: Biological properties, chemical modifications and structural analysis a review. Carbohydr Polym 2009;77:167-80.

42. Chen H, Yan X, Lin J, Wang F, Xu W. Depolymerized products of lambda-carrageenan as a potent angiogenesis inhibitor. J Agric Food Chem 2007;55:6910-7.

43. Lahaye M, Robic A. Structure and functional properties of ulvan, a polysaccharide from green seaweeds. Biomacromolecules 2007;8:1765-74

44. Allen VG, Pond KR, Saker KE, Fontenot JP, Bagley CP, Ivy RL, et al. Tasco: Influence of a brown seaweed on antioxidants in forages and livestock a review. J Anim Sci 2001;79:E21-31.

45. Senn TL. Seaweed and Plant Growth. Clemson, SC: Clemson University; 1987. 
46. Gardiner GE, Campbell AJ, O'JV OO, Pierce E, Lynch PB, Leonard FC, et al. Effect of extract Ascophyllum nodosum on growth performance, digestibility, carcass characteristics and selected intestinal microflora populations of grower finisher pigs. Anim Feed Sci Technol 2008;141:259-73.

47. Gahan DA, Lynch MB, Callan JJ, O'Sullivan JT, O'Doherty JV. Performance of weanling piglets offered low-, medium- or high-lactose diets supplemented with a seaweed extract from Laminaria spp. Animal 2009;3:24-31.

48. Craigie JS. Seaweed extract stimuli in plant science and agriculture. J Appl Phycol 2011;23:371-93.

49. Zhuang G, Yang G, Yu J, Gao Y. Production of DMS and DMSP in different physiological stages and salinity conditions in two marine algae. Chin J Oceanol Limn 2011;29:369-77.

50. Yang Y, Seo JM, Nguyen A, Pham TX, Park HJ, Park Y, et al. Astaxanthin-rich extract from the green alga Haematococcus pluvialis lowers plasma lipid concentrations and enhances antioxidant defense in apolipoprotein E knockout mice. J Nutr 2011;141:1611-7.

51. Cardozo KH, Guaratini T, Barros MP, Falcão VR, Tonon AP, Lopes NP, et al. Metabolites from algae with economical impact. Comp Biochem Physiol C Toxicol Pharmacol 2007;146:60-78.

52. Spolaore P, Joannis-Cassan C, Duran E, Isambert A. Commercial applications of microalgae. J Biosci Bioeng 2006;101:87-96.

53. Thomas NV, Kim SK. Beneficial effects of marine algal compounds in cosmeceuticals. Mar Drugs 2013;11:146-16.

54. Kraan S. Algal polysaccharides, novel applications and outlook. In: Chang CF $2^{\text {nd }}$, editor. Carbohydrates Comprehensive Studies on Glycobiology and Glycotechnology. Rijeka, Croatia: InTech; 2012. p. 489-532.

55. Ryu B, Qian ZJ, Kim MM, Nam KW, Kim SK. Anti-photoaging activity and inhibition of matrix metalloproteinase (MMP) by marine red alga, Corallina pilulifera methanol extract. Radiat Phys Chem 2009;78:98-105.

56. Nagayama K, Iwamura Y, Shibata T, Hirayama I, Nakamura T. Bactericidal activity of phlorotannin from the brown alga Ecklonia kurome. J Antimicrob Chemother 2002;50:889-93.

57. Eom SH, Kang MS, Kim YM. Antibacterial activity of the phaeophyta Ecklonia stolonifera on methicillin-resistant Staphylococcus aureus. J Fish Sci Technol 2008;11:1-6.

58. Braden KW, Blanton JR Jr, Allen VG, Pond KR, Miller MF. Ascophyllum nodosum supplementation: A preharvest intervention for reducing Escherichia coli O157: $\mathrm{H} 7$ and Salmonella spp. in feedlot steers. J Food Prot 2004;67:1824-8.

59. Plaza M, Santoyo S, Jaime L, García-Blairsy Reina G, Herrero M, Señoráns FJ, et al. Screening for bioactive compounds from algae. J Pharm Biomed Anal 2010;51:450-5.

60. Priyadarshani I, Rath B. Commercial and industrial applications of micro algae a review. J Algal Biomass Util 2012;3:89-100.

61. Blunt JW, Copp BR, Munro MH, Northcote PT, Prinsep MR. Marine natural products. Nat Prod Rep 2006;23:26-78

62. Mayer AM, Hamann MT. Marine pharmacology in 2001--2002: Marine compounds with anthelmintic, antibacterial, anticoagulant, antidiabetic, antifungal, anti-inflammatory, antimalarial, antiplatelet, antiprotozoal, antituberculosis, and antiviral activities; affecting the cardiovascular, immune and nervous systems and other miscellaneous mechanisms of action. Comp Biochem Physiol C Toxicol Pharmacol 2005;140:265-86.

63. Carvalho LR, Coata-Neves A, Conserva GA, Brunetti RL, Hentschke GS, Malone CF, et al. Biologically active compounds from cyanobacteria extracts: In vivo and in vitro aspects. Braz J Pharmacogn 2013;23:471-80

64. Available from: https://www.ucsdnews.ucsd.edu/pressrelease/biologists_ engineer algae to make complex anti cancer designer drug.

65. Specht EA, Mayfield SP. Algae-based oral recombinant vaccines. Front Microbiol 2014;5:60.

66. Amer SA, zAL-Harbi MS, AL-Zahrani YA. Protective role of some antioxidants on arsenic toxicity in male mice: Physiological and histopathological perspectives. Biol Med Aligarh 2016;8:266.

67. Niknam M, Paknahad Z, Baghestani A, Hashemi M. Anti-inflammatory effects of dietary antioxidants in patients with coronary artery disease. Endocrinol Metab Syndr 2015;4:207.

68. Yadav RK, Srivastava SK. Effect of arsenite and arsenate on lipid peroxidation, enzymatic and non-enzymatic antioxidants in Zeamays Linn. Biochem Physiol 2015;4:186.

69. PaulisG PP, Farina PF, Cavallini G, Giorgio DG, Barletta D, Rovereto B. Pentoxifylline associated with other antioxidants (multimodal therapy) on patients with Peyronie's disease. Results of a controlled study. Andrology 2014;3:123.

70. Gebrehiwot TK, Asmar T, Gundersen GS, Gebresilase G, Berh N.
Association of total levels of serum antioxidants with periportal fibrosis and intensity of Schistosoma mansoni infections in Cheretee, North East Ethiopia. J Bacteriol Parasitol 2014;6:-220.

71. Temina M, Rezankova H, Rezanka T, Dembitsky VM. Diversity of the fatty acids of the Nostoc species and their statistical analysis. Microbiol Res 2007;162:308-21.

72. Goecke F, Labes A, Wiese J, Imhof JF. Chemical interactions between marine macroalgae and bacteria. MEPS 2010;409:267-99.

73. Umezawa T, Oguri Y, Matsuura H, Yamazaki S, Suzuki M, Yoshimura E, et al. Omaezallene from red alga Laurencia sp.: Structure elucidation, total synthesis, and antifouling activity. Angew Chem Int Ed Engl 2014:53:3909-12.

74. Branen LA, Davidson MP, Salmine NS, Thorngate HJ. Food Additives. New York: Marcel Dekker; 2002.

75. Steffens D, Leonardi D, Soster PR, Lersch M, Rosa A, Crestani T, et al. Development of a new nanofiber scaffold for use with stem cells in a third degree burn animal model. Burns 2014;40:1650-60.

76. de Morais MG, Stillings C, Dersch R, Rudisile M, Pranke P, Costa JA, et al. Preparation of nanofibers containing the microalga Spirulina (Arthrospira). Bioresour Technol 2010;101:2872-6.

77. Matsui MS, Muizzuddin N, Arad S, Marenus K. Sulfated polysaccharides from red microalgae have antiinflammatory properties in vitro and in vivo. Appl Biochem Biotechnol 2003;104:13-22.

78. Kuniyoshi M, Yamada K, HigaT HH. A biologically active diphenyl ether from the green alga Cladophora fascicularis. Experientia 1985;41:523-4.

79. Puglisi MP, Tan LT, Jensen PR, FenicalW FF. Capisterones A and B from the tropical green alga Penicillus capitatus: Unexpected antifungal defenses targeting the marine pathogen Lindra thallasiae. Tetrahedron 2004;60:7035-9.

80. Tariq VN. Antifungal activity in crude extracts of marine red algae. Mycol Res 1991;95:1433.

81. Mickymaray S, Alturaiki W. Antifungal efficacy of marine macroalgae against fungal isolates from bronchial asthmatic cases. Molecules 2018;23:E3032.

82. Pereira MS, Melo FR, Mourão PA. Is there a correlation between structure and anticoagulant action of sulfated galactans and sulfated fucans? Glycobiology 2002;12:573-80

83. Killing H. Zurbiochemie der meersalgen. Zeitschrift fur Physiologische Chemie 1913;83:171-97.

84. Church FC, Meade JB, Treanor RE, Whinna HC. Antithrombin activity of fucoidan. The interaction of fucoidan with heparin cofactor II, antithrombin III, and thrombin. J Biol Chem 1989;264:3618-23.

85. Matsubara K. Recent advances in marine algal anticoagulants. Curr Med Chem Cardiovasc Hematol Agents 2004;2:13-9.

86. Nishino T, Yamauchi T, Horie M, Nagumo T, Suzuki H. Effects of a fucoidan on the activation of plasminogen by u-PA and t-PA. Thromb Res 2000;99:623-34

87. Costa LS, Fidelis GP, Cordeiro SL, Oliveira RM, Sabry DA, Câmara RB, et al. Biological activities of sulfated polysaccharides from tropical seaweeds. Biomed Pharmacother 2010;64:21-8.

88. McLellan DS, Jurd KM. Anticoagulants from marine algae. Blood Coagul Fibrinolysis 1992;3:69-77.

89. Carlucci MJ, Pujol CA, Ciancia M, Noseda MD, Matulewicz MC, Damonte EB, et al. Antiherpetic and anticoagulant properties of carrageenans from the red seaweed Gigartina skottsbergii and their cyclized derivatives: Correlation between structure and biological activity. Int J Biol Macromol 1997;20:97-105.

90. Kolender AA, Pujol CA, Damonte EB, Matulewicz MC, Cerezo AS. The system of sulfated alpha-(1-->3)-linked D-mannans from the red seaweed Nothogenia fastigiata: Structures, antiherpetic and anticoagulant properties. Carbohydr Res 1997;304:53-60.

91. Sen AK Sr, Das AK, Banerji N, Siddhanta AK, Mody KH, Ramavat BK, et al. A new sulfated polysaccharide with potent blood anti-coagulant activity from the red seaweed Grateloupia indica. Int J Biol Macromol 1994; 16:279-80.

92. Chevolot L, Foucault A, Chaubet F, Kervarec N, Sinquin C, Fisher AM, et al. Further data on the structure of brown seaweed fucans: Relationships with anticoagulant activity. Carbohydr Res 1999;319:154-65.

93. Colliec S, Fischer AM, Tapon-Bretaudiere J, Boisson C, Durand P, Jozefonvicz J. Anticoagulant properties of a fucoïdan fraction. Thromb Res 1991;64:143-54

94. Dobashi K, Nishino T, Fujihara M, Nagumo T. Isolation and preliminary characterization of fucose-containing sulfated polysaccharides with blood-anticoagulant activity from the brown seaweed hizikia fusiforme. Carbohydr Res 1989;194:315-20.

95. Gerber P, Dutcher JD, Adams EV, Sherman JH. Protective effect of seaweed extracts for chicken embryos infected with influenza B or 
mumps virus. Proc Soc Exp Biol Med 1958;99:590-3

96. Huheihel M, Ishanu V, Tal J, Arad SM. Activity of Porphyridium sp. polysaccharide against herpes simplex viruses in vitro and in vivo. J Biochem Biophys Methods 2002;50:189-200.

97. Witvrouw M, De Clercq E. Sulfated polysaccharides extracted from sea algae as potential antiviral drugs. Gen Pharmacol 1997;29:497-511.

98. Gerber P, Dutcher JD, Adams EV, Sherman JH. Inhibition of herpes virus replication by marine algae extracts. Proc Soc Exp Biol Med 1958;99:590-3.

99. Queiroz KC, Medeiros VP, Queiroz LS, Abreu LR, Rocha HA, Ferreira $\mathrm{CV}$, et al. Inhibition of reverse transcriptase activity of HIV by polysaccharides of brown algae. Biomed Pharmacother 2008;62:303-7.

100. Mori T, O'Keefe BR, Sowder RC $2^{\text {nd }}$, Bringans S, Gardella R, Berg S, et al. Isolation and characterization of griffithsin, a novel HIVinactivating protein, from the red alga Griffithsia sp. J Biol Chem 2005;280:9345-53.

101. Akbarzadeh S, Gholampour H, Farzadinia P, Daneshi A, Ramavandi B, Moazzeni A, et al. Anti-diabetic effects of Sargassum oligocystum on streptozotocin-induced diabetic rat. Iran J Basic Med Sci 2018;21:342-6.

102. Lee YS, Shin KH, Kim BK, Lee S. Anti-diabetic activities of fucosterol from Pelvetia siliquosa. Arch Pharm Res 2004;27:1120-2.

103. Ohta T, Sasaki S, Oohori T, Yoshikawa S, Kurihara H. Alphaglucosidase inhibitory activity of a $70 \%$ methanol extract from ezoishige (Pelvetia babingtonii de Toni) and its effect on the elevation of blood glucose level in rats. Biosci Biotechnol Biochem 2002;66:1552-4

104. Taylor WR. Marine Algae of the Northeastern Coast of North America. Ann Arbor: The University Michigan Press; 1957. p. 126

105. Apostolidis E, Karayannakidis PD, Kwon YI, Lee CM, Seeram NP. Seasonal variation of phenolic antioxidant-mediated $\alpha$-glucosidase inhibition of Ascophyllum nodosum. Plant Foods Hum Nutr 2011;66:313-9.

106. Okada Y, Ishimaru A, Suzuki R, Okuyama T. A new phloroglucinol derivative from the brown alga Eisenia bicyclis: Potential for the effective treatment of diabetic complications. J Nat Prod 2004;67:103-5.

107. D'Orazio N, Gemello E, Gammone MA, de Girolamo M, Ficoneri C, Riccioni G. Fucoxantin: A treasure from the sea. Mar Drugs 2012;10:604-16.

108. BelHadj S, Hentati O, Elfeki A, Hamden K. Inhibitory activities of Ulva lactuca polysaccharides on digestive enzymes related to diabetes and obesity. Arch Physiol Biochem 2013;119:81-7.
109. Celikler S, Tas S, Vatan O, Ziyanok-Ayvalik S, Yildiz G, Bilaloglu R. Anti-hyperglycemic and antigenotoxic potential of Ulva rigida ethanolic extract in the experimental diabetes mellitus. Food Chem Toxicol 2009; 47:1837-40.

110. Tas S, Celikler S, Ziyanok-Ayvalik S, Sarandol E, Dirican M. Ulva rigida improves carbohydrate metabolism, hyperlipidemia and oxidative stress in streptozotocin-induced diabetic rats. Cell Biochem Funct 2011;29:108-13.

111. Yuan YV, Walsh NA. Antioxidant and antiproliferative activities of extracts from a variety of edible seaweeds. Food Chem Toxicol 2006; $44: 1144-50$

112. Available from: C:/Users/MS\%20RAJAH/Desktop/Journals/ Economic\%20imp/TOP\%2016\%20Economic\%20Importance $\% 20$ of $\%$ s20ALGAE $\% 20 \% 20$ Biology.pdf.

113. Palaniswamy R, Veluchamy C. Spirulina a review on nutritional perspective. Int J Recent Sci 2017;8:19825-7.

114. Kumar CS, Ganesan P, Suresh PV, Bhaskar BB. Seaweeds as a source of nutritionally beneficial compounds a review. N J Food Sci Technol 2008;45:1-13.

115. Nisizawa K. Seaweeds Kaiso Bountiful Harvest from the Seas Sustenance For Health and Well Being by Preventing Common Life Style Diseases. Japan: Japan Seaweed Association; 2002. p. 59-68.

116. Veer S. What is the economic importance of Algae? IST 2019;13:6.

117. Souza PO, Ferreira LR, Pires NR, Filho PJ, Duarte FA, Pereira CM, et al. Algae of economic importance that accumulate cadmium and lead: A review. Rev Bras Farmacogn 2012;22:825-37.

118. Watanabe A. Distribution of nitrogen fixing blue-green algae in various areas of South and East Asia. J Gen ApplMicrobiol 1959;5:1-2.

119. Available from: https://www.alliedmarketresearch.com/pressrelease/algaeproducts-market.html.

120. Kurian V. India can be a World Leader in Algal Farming, says us Expert. Agri Business; 2018.

121. Available from: https://www.yourstory.com/mystory/ee3a8c48b2can-india-be-a-world-leader-in-marine-algal-farming.

122. Sharma N, Sharma P. Industrial and biotechnological applications of algae: A review. J Appl Pharm Sci 2017;1:1-25.

123. Wells ML, Potin P, Craigie JS, Raven JA, Merchant SS, Helliwell KE, et al. Algae as nutritional and functional food sources: Revisiting our understanding. J Appl Phycol 2017;29:949-82.

124. Raja A, Vipin C, Aiyappan A. Biological importance of marine algae an overview. Int J Curr Microbiol Appl Sci 2013;2:222-7.

125. Available from: https://www.goerlich-pharma.com/en/omega-3fatty-acids-algae-oil. 